Article

\title{
Export of Dissolved Organic Carbon from the Source Region of Yangtze River in the Tibetan Plateau
}

\author{
Xiaoni You ${ }^{1}$, Xiangying $\mathrm{Li}^{2,3, *}$, Mika Sillanpää ${ }^{4,5}{ }^{-0}$, Rong Wang ${ }^{1}$, Chengyong $\mathrm{Wu}^{1}$ and Qiangqiang $\mathrm{Xu}^{1}$ \\ 1 College of Resources and Environmental Engineering, Tianshui Normal University, Tianshui 741001, China; \\ yxiaoni@tsnu.edu.cn (X.Y.); 0119061@stu.lzjtu.edu.cn (R.W.); giswuchengyong@163.com (C.W.); \\ xudizhi918@163.com (Q.X.) \\ 2 Shaanxi Key Laboratory of Earth Surface System and Environmental Carrying Capacity, \\ Northwest University, Xi'an 710127, China \\ 3 College of Urban and Environmental Sciences, Northwest University, Xi'an 710127, China \\ 4 Department of Chemical Engineering, School of Mining, Metallurgy and Chemical Engineering, \\ University of Johannesburg, Doornfontein 17011, South Africa; mikas@uj.ac.za \\ 5 Department of Biological and Chemical Engineering, Aarhus University, 8000 Aarhus, Denmark \\ * Correspondence: lixy@nwu.edu.cn
}

Citation: You, X.; Li, X.; Sillanpää, M. Wang, R.; Wu, C.; Xu, Q. Export of Dissolved Organic Carbon from the Source Region of Yangtze River in the Tibetan Plateau. Sustainability 2022, 14, 2441. https://doi.org/10.3390/ su14042441

Academic Editor: Ashwani Kumar Tiwari

Received: 8 December 2021

Accepted: 14 February 2022

Published: 21 February 2022

Publisher's Note: MDPI stays neutral with regard to jurisdictional claims in published maps and institutional affiliations.

Copyright: (C) 2022 by the authors. Licensee MDPI, Basel, Switzerland. This article is an open access article distributed under the terms and conditions of the Creative Commons Attribution (CC BY) license (https:// creativecommons.org/licenses/by/ $4.0 /)$.

\begin{abstract}
The carbon release and transport in rivers are expected to increase in a warming climate with enhanced melting. We present a continuous dataset of DOC in the river, precipitation, and groundwater, including air temperature, discharge, and precipitation in the source region of the Yangtze River (SRYR). Our study shows that the average concentrations of DOC in the three endmembers are characterized as the sequence of groundwater $>$ precipitation $>$ river, which is related to the water volume, cycle period, and river flow speed. The seasonality of DOC in the river is observed as the obvious bimodal structure at Tuotuohe (TTH) and Zhimenda (ZMD) gauging stations. The highest concentration appears in July $\left(2.4 \mathrm{mg} \mathrm{L}^{-1}\right.$ at TTH and $2.1 \mathrm{mg} \mathrm{L}^{-1}$ at ZMD) and the secondary high value (2.2 $\mathrm{mg} \mathrm{L}^{-1}$ at TTH $1.9 \mathrm{mg} \mathrm{L}^{-1}$ at ZMD) emerges from August to September. It is estimated that 459 and 6751 tons of DOC are transported by the river at TTH and ZMD, respectively. Although the wet deposition flux of DOC is nearly ten times higher than the river flux, riverine DOC still primarily originates from soil erosion of the basin rather than precipitation settlement. Riverine DOC fluxes are positively correlated with discharge, suggesting DOC fluxes are likely to increase in the future. Our findings highlight that permafrost degradation and glacier retreat have a great effect on DOC concentration in rivers and may become increasingly important for regional biogeochemical cycles.
\end{abstract}

Keywords: DOC; groundwater; precipitation; river water; Yangtze River

\section{Introduction}

The dissolved organic carbon (DOC) amounts in river ecosystems are potentially increasing with global warming as the extensive release from permafrost and glaciers occurs [1,2]. Previous studies have shown that the soil organic carbon (SOC) reserves in the Arctic and sub-Arctic regions are about $1700 \mathrm{pg}$, which is twice the carbon in the atmosphere at present [3,4], accounting for 23 to $48 \%$ of the global soil organic carbon reserves [5]. Affected by global warming, the organic carbon sequestered in permafrost is released gradually as the active layer thickens [6], which, in turn, aggravates climate change. Glacier ablation causes the release of glacier organic carbon (OC) and enhances water soil/rock interaction and microbial activity by changing the hydrological process in cold regions, affecting the ecological environment and carbon cycle, and reacting on the climate $[7,8]$. This process depends on the environmental characteristics of the basin, the occurrence conditions, melting sensitivity, and degradation mode of glacier elements [9]. The study shows that the current OC reserved in mountain glaciers accounts for about $2.2 \%$ 
of the global OC reserves in glaciers, while the OC ( $1.28 \mathrm{pg} /$ year) released by meltwater runoff from mountain glaciers is about $42.5 \%$ of the global OC emissions in glaciers [10].

$\mathrm{OC}$ is released from the frozen soil and glacier by dissolving in water and then flows into the river with the meltwater [11]. It is not only an important part of the carbon cycle in the cryosphere but affects the structure and function of the river ecosystem [12]. Recent investigation demonstrates that, in riverine export, $41 \%$ of terrestrially derived DOC is delivered to the coastal ocean, $21 \%$ is buried in sediment, and the remaining $38 \%$ is returned to the atmosphere through outgassing from inland waters $[13,14]$. DOC in river water has a close impact on the dynamic of the aquatic biogeochemical cycle, light penetration, transportation of trace metals, secondary production, and the flow of nitrogen [15-19]. It is also considered to increase the solubility of some organic pollutants in water [20]. DOC levels change over time and space due to the complexity of catchments and aquatic ecosystems. Many variables may affect riverine DOC concentrations, for instance, discharge, basin precipitation, air temperature, metabolism of phytoplankton, atmospheric carbon dioxide concentration, internal production, and mineralization of carbon [21-26]. Anthropogenic activities play a substantial role in the transport of riverine DOC, e.g., acid deposition, nitrogen deposition, and agricultural activities [27-30]. In particular, land use and cover change, fire, and forest species greatly affect the variation of SOCs, which further alter the riverine DOC amount [31-34].

The annual runoff from the source region of the Yangtze River (SRYR) has been increasing due to the recession of glaciers and permafrost [35]. As one of the world's largest rivers, information on the nature and quantity of carbon transported by the Yangtze River has attracted research interests in past years [23,36-38]. It is concluded that the export of total organic carbon (TOC) from the Yangtze River at the end of the 20th century is approximately equivalent to that of the Zaire River [23]. Soil erosion and vascular plant input separately dominate the main source in tributaries north and south of the Yangtze River trunk stream. The DOC concentration is lower in the sparsely populated area but is higher in the downstream, dominated by anthropogenic input mainly [38]. To determine the sources and ages of organic matter, the stable carbon $\left({ }^{13} \mathrm{C}\right)$ and natural radiocarbon $\left({ }^{14} \mathrm{C}\right)$ abundances are measured for riverine OC $[23,39,40]$. The results indicate that the isotopic signature of particulate organic matter (POM) is similar to that of the surface soil along the riverbank [23], reflecting the typical stable carbon isotope source signatures of terrestrial organic matter [39]. The OC fluxes and their control factors are also discussed widely, and a relatively consistent result is obtained that the magnitude and seasonal variability of the TOC fluxes are evidently controlled by the discharge and suspend sediment concentrations (SSC) [36].

Most studies of OC transport in the Yangtze River have concentrated on the downstream reaches and estuary to examine the fluxes of OC entering the coastal oceans. However, less attention is focused on the SRYR based on limited sampling events. To obtain a comprehensive understanding of the DOC in the SRYR, we need to make clear how much DOC is transported and allocated under the impact of the meteorological and hydrological factors. In this study, we carry out field collection of river, precipitation, and groundwater samples at Zhimenda (ZMD) and Tuotuohe (TTH) gauging stations in 2014 and 2015. Considering that the Tibetan Plateau has been greatly affected by climate change in the past few decades, we employ discharge, precipitation, and air temperature data, for which profound changes have taken place under the influence of global warming, to compare the spatiotemporal distributions of DOC in different end-elements and explore its potential relationship with the hydrometeorological factors. The aim of this work is obtaining the seasonal characteristics of the DOC concentration in the SRYR and quantifying the DOC deposition flux and river transport flux in the watershed to help elucidate the role of future climate-driven glacier retreat and permafrost degradation and DOC export in regional biochemical elemental cycles. An important feature of the research is high frequency (once every two days) water sampling at sampling points, which makes it possible to acquire a detailed understanding of both seasonal variations in the DOC concentrations and potential 
influence factors. This is the first study that collects and compares the DOC concentrations from rivers, precipitation, and groundwater in a basin simultaneously, thereby providing a research path to understand the delivery and allocation of DOC in the SRYR.

\section{Materials and Methods}

\subsection{Study Area and Sampling Site}

The SRYR $\left(90^{\circ} 43^{\prime}-96^{\circ} 45^{\prime} \mathrm{E}\right.$ and $\left.32^{\circ} 30^{\prime}-35^{\circ} 35^{\prime} \mathrm{N}\right)$ located in the central east part of the Tibetan Plateau is defined as the area north of ZMD station (Figure 1). The mean altitude reaches $4000 \mathrm{~m}$ with a decreasing elevation from west to east [40] that covers an area of approximately $12.24 \times 10^{4} \mathrm{~km}^{2}$, dominating $7.8 \%$ of the total area of the Yangtze River basin (Figure 1b). The glaciers in the SRYR spread a total area of $1496 \mathrm{~km}^{2}$, primarily along the north-oriented slopes of the Tanggula Mountains, Sedir Mountains, and the southoriented slopes of the Kunlun Mountains, with annual ablation of $11.87 \times 10^{8} \mathrm{~m}^{3}$ [41] In addition to the large-scale distribution of wetlands, permafrost accounts for $77 \%$ of the total basin area, with a thickness of 10-120 m (Figure 1a). Most surface soils freeze during winter and thaw in summer, and active layer thicknesses range from 1-4 $\mathrm{m}$ [42]. Controlled by a typical cold plateau climate, the annual average temperatures in the SRYR fluctuate from 3 to $5.5^{\circ} \mathrm{C}$, and the annual precipitations range from 222 to $515 \mathrm{~mm}$; roughly $80 \%$ of the annual precipitations occur in summer $[43,44]$. Fieldwork was conducted at the Tuotuohe (TTH) $\left(34^{\circ} 23^{\prime \prime} \mathrm{N}, 92^{\circ} 45^{\prime \prime} \mathrm{E}, 4533 \mathrm{~m}\right.$ a.s.l.) and Zhimenda (ZMD) $\left(33^{\circ} 01^{\prime \prime} \mathrm{N}\right.$, $97^{\circ} 24^{\prime \prime} \mathrm{E}, 3681 \mathrm{~m}$ a.s.1.) hydrological stations, located in the hinterland and east of the SRYR, respectively, occupying an area of approximately $1.5 \times 10^{4} \mathrm{~km}^{2}$ above the TTH, and $13.2 \times 10^{4} \mathrm{~km}^{2}$ above the ZMD.

\subsection{Sample Collection}

Bulk river samples were taken at two-day intervals from May to October of 2015 at TTH and ZMD to observe the seasonal process of DOC concentrations and relevant drainage system in the SRYR. Precipitation samples were collected from May to October of 2014 at TTH and same period in 2015 at ZMD when precipitation occurred. In consideration of the relative stability of groundwater, samples were taken at five-day intervals from the well water near the hydrological station from May to October of 2015 at both sites. The samples used for DOC analysis were immediately filtered through precombusted Whatman glass fiber membranes (pore size $0.7 \mu \mathrm{m}$ ) once sampling finished. We pre-cleaned the sampling and storage containers using 10\% hydrochloric acid and MilliQ deionized water [45]. Field samples were kept frozen in a refrigerator and then transported to the State Key Laboratory of Cryospheric Science (SKLCS) of Chinese Academy of Sciences (CAS) and Environmental Comprehensive Analysis Laboratory (ECAL) of Tianshui Normal University (TNU) for chemical analysis (Li et al., 2018). Total of 438 samples were collected and analyzed. Furthermore, discharge, temperature, and precipitation data were provided, respectively, by TTH and ZMD hydrological stations and Tuotuohe (TTHW) $\left(34^{\circ} 22^{\prime} \mathrm{N}\right.$, $\left.92^{\circ} 43^{\prime} \mathrm{E}\right)$ and Yushu (YS) $\left(33^{\circ} 02^{\prime} \mathrm{N}, 97^{\circ} 02^{\prime} \mathrm{E}\right)$ national weather stations (Figure 1$)$.

\subsection{Laboratory Analysis}

All samples used for DOC testing were filtered before analysis in the laboratory using precombusted Whatman glass fiber membranes of $0.45 \mu \mathrm{m}$ of pore size. Then, they were analyzed by Vario EL TOC/TNb analyzer (Elementar, Hanau, Germany) in the ECAL of TNU. The system was calibrated using potassium hydrogen phthalate standards for DOC. The detection limits were below $30 \mu \mathrm{g} \mathrm{L}^{-1}$, and the reproducibility was lower than 5\% [45]. Mean blank value was detected as $76 \mu \mathrm{g} \mathrm{L}^{-1}$, which was subtracted by the measured DOC value. Concentration of cations $\left(\mathrm{Ca}^{2+}\right)$ and anions $\left(\mathrm{Cl}^{-}\right.$and $\left.\mathrm{NO}_{3}{ }^{-}\right)$were analyzed by Dionex-600 and Dionex-2500 ion chromatography, respectively, separately using a CS12A separation column, $20 \mathrm{mM}$ MSA eluent, and CSRS-ULTRA-II suppressor and an IonPac AS11-HC column, $25 \mathrm{mM}$ KOH eluent, and ASRSULTRA-II suppressor in the SKLCS of 
CAS. The detection limits were below $10 \mu \mathrm{g} \mathrm{L}^{-1}$ and the precision was better than $\pm 1 \%$ for all measured ions [46].
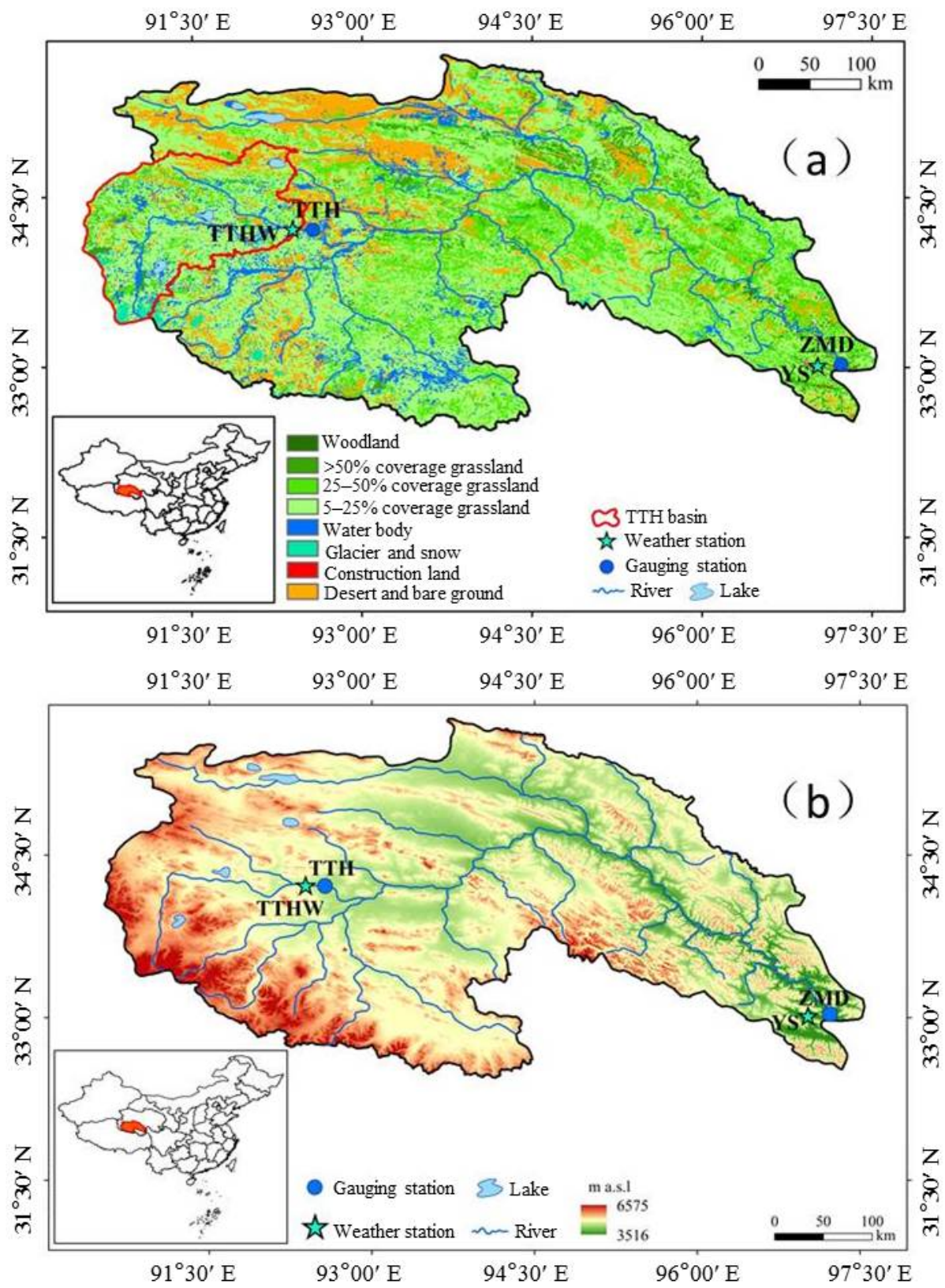

Figure 1. Location, land cover (a), and topography (b) of the study area and observation sites along the Yangtze River trunk stream (TTH: Tuotuohe gauging station, ZMD: Zhimenda gauging station, YS: Yushu weather station, TTHW: Tuotuohe weather station).

\subsection{Flux Calculation and Ion Ratio}

To calculate the daily DOC fluxes $\left(F_{d}\right)$ from rivers at TTH and ZMD, we used daily runoff $\left(Q_{d}\right)$ multiplied by daily DOC concentrations $\left(C_{d}\right)$ to produce daily DOC fluxes (Equation (1)). Annual DOC flux (Fy) was estimated by the product of annual runoff $\left(Q_{c}\right)$ and mean DOC concentration $\left(\overline{C_{d}}\right)$ in the investigation period (Equation (2)). The approaches are simplistic but provide an estimate of DOC fluxes on the regional scales $[10,47]$.

$$
\begin{aligned}
& F_{d}=Q_{d} \times C_{d} \\
& F_{y}=Q_{C} \times \overline{C_{d}}
\end{aligned}
$$


Equally, daily wet deposition fluxes of DOC at sampling sites were calculated by daily precipitation multiplied by DOC concentration. Annual wet deposition flux was obtained through annual mean DOC concentration in precipitation multiplied by the annual precipitation. The deposition flux of DOC in the whole basin was estimated as the DOC annual deposition flux multiplied by the watershed area. The approaches taken assumed that the available data are representative of entire drainage area, which is unlikely given the differences in climate, hydrology, and land cover. That was the possible error.

This paper utilized ratios of $\left[\mathrm{Ca}^{2+}\right] /\left[\mathrm{Cl}^{-}\right]$and $\left[\mathrm{NO}_{3}{ }^{-}\right] /\left[\mathrm{Ca}^{2+}\right]$ to track water pathways [48]. $\mathrm{Cl}^{-}$was considered as relatively conservative ion in aquatic environments, rarely participating in biological and geochemical processes, and mainly coming from rainwater [49]. Dissolved $\mathrm{Ca}^{2+}$ mainly originated from the weathering of carbonates, silicates, and evaporites [50-52]. As such, $\left[\mathrm{Ca}^{2+}\right] /\left[\mathrm{Cl}^{-}\right]$ratios can be used to compare the relative mobilization of chemical weathering products during the different seasons. In contrast, $\mathrm{NO}_{3}{ }^{-}$was strongly linked to nutrient cycling in organic matter in near surface soils. We, therefore, employed $\left[\mathrm{NO}_{3}{ }^{-}\right] /\left[\mathrm{Ca}^{2+}\right]$ ratio to assess the relative influence of organic matter cycling versus mineral weathering [48]. Ions and DOC in rivers have different natural sources; however, both are affected by atmospheric and hydrological processes. Discussing the relationship between them could help us to further comprehend the seasonal variation and influence factors of riverine DOC.

\section{Results}

The monthly mean concentrations of DOC from the three end-members are presented in Figure 2. The DOC concentrations in river water and groundwater range from 0.7 to $2.5 \mathrm{mg} \mathrm{L}^{-1}$ and 1.0 to $1.9 \mathrm{mg} \mathrm{L}^{-1}$ at TTH, respectively; they fluctuate between 0.2 and $2.8 \mathrm{mg} \mathrm{L}^{-1}, 0.6$ and $2.0 \mathrm{mg} \mathrm{L}^{-1}$ as well as 0.5 and $2.6 \mathrm{mg} \mathrm{L}^{-1}$ from the river, groundwater, and precipitation at ZMD. High concentrations are clearly distinguished during the period from May to August at both sites, when they reach the maximum of $1.85 \mathrm{mg} \mathrm{L}^{-1}$ (August), $1.68 \mathrm{mg} \mathrm{L}^{-1}$ (August), and $1.65 \mathrm{mg} \mathrm{L}^{-1}$ (July) at TTH, $1.54 \mathrm{mg} \mathrm{L}^{-1}$ (July), $1.51 \mathrm{mg} \mathrm{L}^{-1}$ (July), and $1.62 \mathrm{mg} \mathrm{L}^{-1}$ (May) at ZMD in the three end-members (Figure 2).

Oct

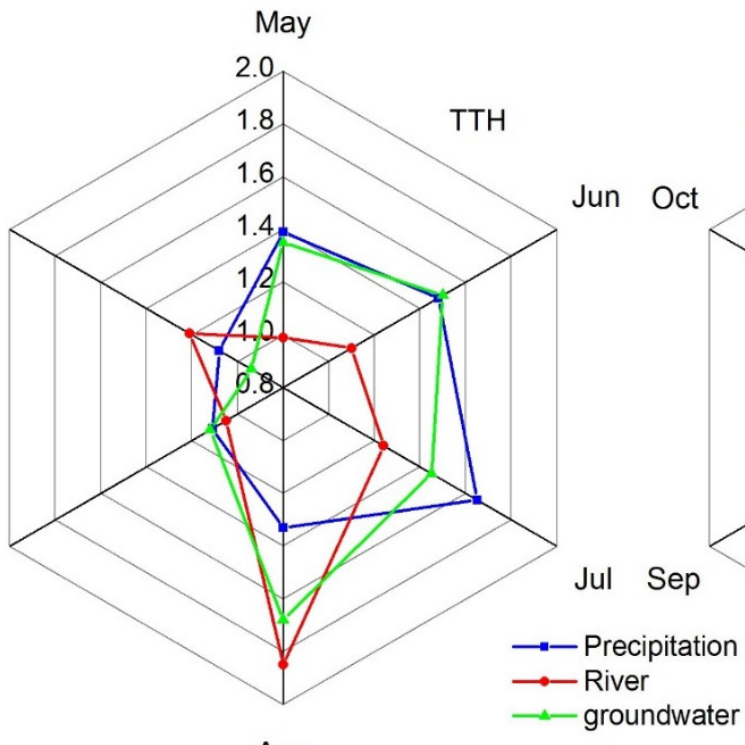

Aug

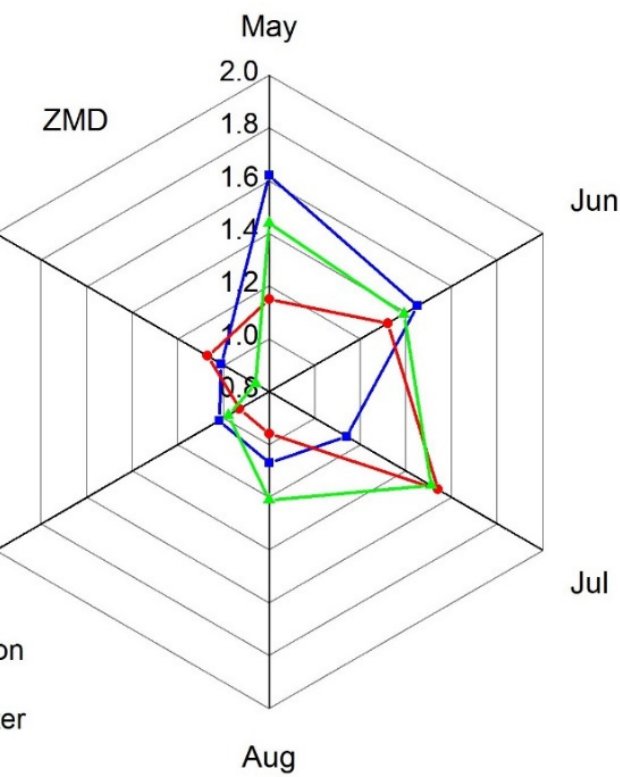

Jul

Figure 2. Monthly mean concentrations of dissolved organic carbon (DOC) in precipitation, river, and groundwater from May to October at Tuotuohe (TTH) and Zhimenda (ZMD) gauging stations.

In order to explore the impact of meteorological and hydrological factors on DOC concentration, Figure 3 shows the daily DOC concentration in the different end-members compared with the daily mean air temperature, precipitation amount, and discharge at TTH and ZMD, respectively. The mean riverine DOC concentrations at TTH and ZMD are 
$1.24 \mathrm{mg} \mathrm{L}^{-1}$ and $1.16 \mathrm{mg} \mathrm{L}^{-1}$, respectively, based on data from May to October in 2015. The concentrations are lower and more stable from May to June at TTH, then exhibit two large fluctuations in July and August-September; finally, they drop back and keep stable again after October (Figure 3a). For ZMD, the concentrations are lower and more stable in May and June before reaching their highest at the end of June. Then, they drop to their lowest in early August before reaching to the sub-peak in September; finally, they decrease and fluctuate slightly in October (Figure $3 b$ ). Evidently, the runoff indicates similar seasonal variation. At TTH, the river discharge increases from 14 to $38 \mathrm{~m}^{3} \mathrm{~s}^{-1}$ in May and June up to the maximum of 35 to $171 \mathrm{~m}^{3} \mathrm{~s}^{-1}$ in late June and early July with a distinct enhance in DOC concentrations from 0.8 to 1.2 to 1.5 to $2.4 \mathrm{mg} \mathrm{L}^{-1}$ (Figure 3c). One notable discharge peak is observed from the end of June to early July $\left(1537 \mathrm{~m}^{3} \mathrm{~s}^{-1}\right)$ at $\mathrm{ZMD}$, which is consistent with the first fluctuation of riverine DOC. While the river flow from mid-August to late September is not obvious (ranges from $401 \mathrm{~m}^{3} / \mathrm{s}$ to $619 \mathrm{~m}^{3} / \mathrm{s}$ ), it still gives rise to the fluctuation in riverine DOC concentration (Figure 3d). Two intense precipitation events, from the middle of May to the middle of July and from August to the middle of September, correspond well to the two runoff peaks and DOC concentration peaks at both stations. At ZMD, the mean DOC concentration in the precipitation is $1.3 \mathrm{mg} \mathrm{L}^{-1}$ in 2015 , which is comparable with that in Lhasa $\left(1.10 \mathrm{mg} \mathrm{L}^{-1}\right)$ [53], and slightly lower than that in Beijing (3.5 $\mathrm{mg} \mathrm{L}^{-1}$ ) [54]. Compared with the river and precipitation, the DOC concentration in the groundwater is rather stable and shows a slow downward trend during the observation period, which could be well fitted by exponential function with the fitting degrees of 0.8 $(n=58, \mathrm{ZMD})$ and $0.6(n=34, \mathrm{TTH})$, respectively.
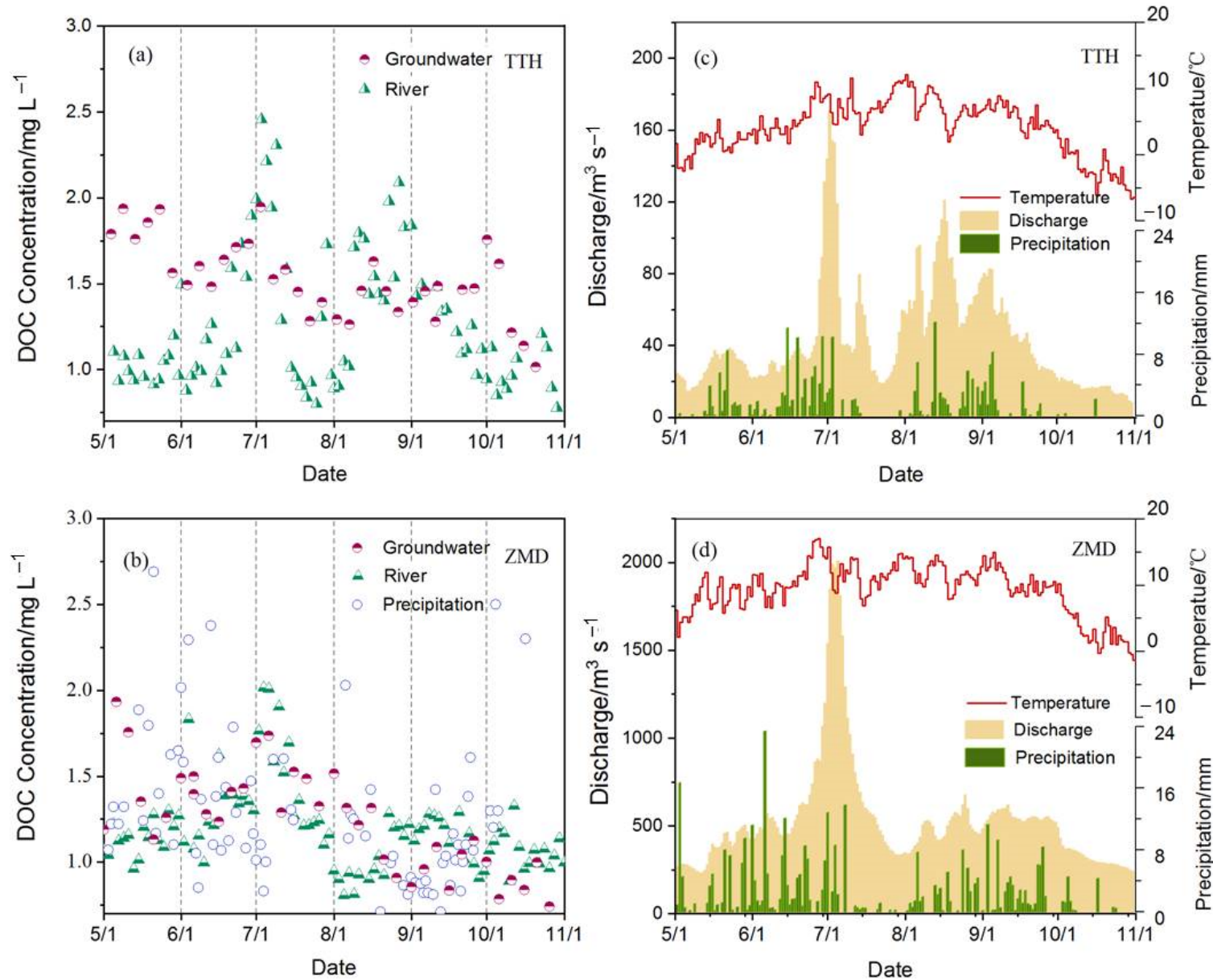

Figure 3. Seasonal variations of DOC concentration, air temperature, discharge, and precipitation from May to October of 2015. (a) DOC concentration in river and groundwater at TTH; (b) DOC 
concentration in river, precipitation, and groundwater at ZMD; (c) daily air temperature, discharge, and precipitation at TTH; (d) daily air temperature, discharge, and precipitation at ZMD.

\section{Discussions}

\subsection{Controls of Meteorological and Hydrological Elements on DOC Concentration}

The average concentrations of the riverine DOC at TTH and ZMD are comparable with the values detected in $1997\left(1.26 \mathrm{mg} \mathrm{L}^{-1}\right)$ and $2003\left(1.29 \mathrm{mg} \mathrm{L}^{-1}\right)$ [23] based on the whole main stream of Yangtze River. The value is slightly lower than the rivers in the Tibetan Plateau $\left(2.09 \pm 0.41 \mathrm{mg} \mathrm{L}^{-1}\right)$ [37], and much lower than those in the tropical area (5.2-9.0 $\left.\mathrm{mg} \mathrm{L}^{-1}\right)$ [24], Arctic regions $\left(12 \mathrm{mg} \mathrm{L}^{-1}\right)$ [55], and the global average (5.9 $\mathrm{mg} \mathrm{L}^{-1}$ ) [56]. The lower DOC concentration in the SRYR is likely related to the lower river temperature since a significant negative relationship exists between the DOC concentrations and water temperature in Yangtze River [57]. The unproductive vegetation is probably another reason for the lower DOC concentration. In the catchment areas of TTH and $\mathrm{ZMD}$, the vegetation is sparse, dominated by desert, bare ground, and less than $50 \%$ of coverage grassland (Figure 1a). Generally, a watershed with low vegetation cover usually means a colder climate and inert biological activities, which may prevent the generation of DOC [58-60].

The results show that the variation trend of the DOC concentration at both sites could be explained well by the change in discharge, which follows many previous research studies $[37,38,46]$. The first flow peak accompanied by the rapid increase in air temperature in July initiate the prominent rise in DOC concentration at TTH and ZMD, which is believed to be caused by both precipitation and glacier/permafrost/frozen soil melting $[36,45]$. Increasing snowmelt and/or runoff at the beginning of the ablation period (spring or early summer) causes sharp accumulation and input in allochthonous DOC [61]. The meltwater runoff is limited on the soil surface due to the still frozen soils and immersion with decrepit plants and detritus, while the meltwater concentrates near the snow-soil interface or soil surface. This process that facilitates the separation of DOC from senescent plants would lead to the DOC concentration peak in early summer [62]. The flow sub-peak from August to September is probably caused by increasing temperature, frequent precipitation, and more ablation, which brings about the fluctuation in the DOC concentration once again and produces the sub-peak in the DOC concentration at both sites (Figure 3). More meltwater infiltrates into the deeper soil layers and makes OC transformation and transport possible [63]. However, the bulk DOCs in the surface soils have been delivered in the first flow peak, leading to an apparent weakening of the second DOC peak.

The DOC in the groundwater is relatively stable, with higher values in early May and lower values in October. In late spring, the snow cover and permafrost active layer are gradually melting as temperatures rise, which increases the hydrogeologic connectivity, enhances the drainage of the surface soil [64], and leads to the temporary increase in the water storage capacity $[65,66]$. Consequently, organic soils can be undersaturated prior to refreezing again. Under this regime, bulk meltwater infiltrates the soils in spring rather than entering streams as surface runoff [66]. The meltwater fully mingles with the microorganisms and organic residues in the soil layer, resulting in a high DOC concentration in the groundwater. As the temperature and precipitation go up from June to August, ablation is further intensified and the melting depth of the permafrost active layer is approximately $>80 \mathrm{~cm}[46,67]$. Moreover, percolating meltwater supplies sensible heat to the soil, bringing about the further thawing of the upper permafrost table and the expansion of hydrologically connected pathways $[68,69]$. Organic-rich material concentrated below the active layer can be mobilized by this subsurface flow of water, and subsequently increase the discharge of groundwater to the surface river flow [69-71]. A slight increase in the DOC concentration in the groundwater caused by precipitation recharge is observed in Figure 3, providing an idea to understand DOC migration under the influence of the local water cycle. Despite several slight fluctuations existing, the DOC in groundwater generally 
takes on a downward trend, signifying that the increase in the groundwater volume has a dilution effect on the DOC concentration.

Generally, rainwater DOC has multiple sources, including precipitation, mineral dust, fossil fuel, and biomass burning activities $[53,72,73]$. In our study, the DOC concentrations in the precipitation may be concerned with precipitation amount and frequency because the area is sparsely populated and human activities are limited. Our conclusion is also based on the fact that $80 \%$ of the precipitation is concentrated in July and August, with a higher mean DOC concentration $\left(1.6 \mathrm{mg} \mathrm{L}^{-1}\right)$ (Figure 3$)$. The variation trend of DOC concentration in precipitation and groundwater shows great similarity (Figure 3c), suggesting the significant supply of precipitation to the groundwater. The mean DOC concentration indicates the sequence of underground $>$ precipitation $>$ river at both sites. The reason for the lower riverine DOC concentration could be understood as its large water volume and fast river flow speed. Owing to the weak hydraulic connection with the surface water, slow water renewal cycle, and flow velocity, the DOC concentration in the groundwater is relatively higher since slow flow velocity provides more chance for the groundwater immersing with decrepit plants in the soil, which is beneficial for DOC separating from senescent plants [62].

\subsection{Fluxes of DOC in River and Precipitation}

Figure 4 shows the daily and cumulative river discharges, precipitations, and DOC fluxes at the TTH and ZMD stations. The precipitation amounts and fluxes at TTH come from the data of 2014. Noticeably, the DOC fluxes in the river are closely correlated with river discharge. The cumulative discharge and fluxes ascend rapidly when the first runoff peak arrives in July, with the largest values of 17.3 tons at TTH and 342.9 tons at ZMD, respectively. The DOC fluxes at TTH present an apparent bimodal structure, which is also consistent with the change of runoff (Figure 4c). After the first peak appears in early July (17.3 tons), the DOC fluxes decrease significantly to 1.4 tons by the end of July. The second flux peak occurs in mid-August (the maximum is 16.1 tons), and then continues to decline and gradually stabilize. The first and second flux peaks account for $22 \%$ and $21 \%$, respectively, of the gross DOC flux during the sampling period at TTH. At ZMD, the daily DOC fluxes of the river indicate a single peak style; the maximum presented in early July accounts for $35 \%$ of the gross flux. They decrease and remain at a relatively lower level after the highest value emerges, which is basically synchronized with the change in river runoff (Figure $4 \mathrm{~d}$ ). The annual discharges are $3.7 \times 10^{3} \mathrm{~m}^{3}$ at TTH and $58.2 \times 10^{4} \mathrm{~m}^{3}$ at ZMD, which transport an estimated 459 and 6751 tons of DOC, respectively, at the two sites.

The determination of the DOC deposition fluxes gives us a chance to understand the wet deposition of the DOC in the watershed and its possible relationship with that delivered by river water. The daily wet deposition of DOC ranges from 0.76 to $55.4 \mathrm{mg} \mathrm{m}^{-2}$ day $^{-1}$ at TTH, with the mean value of $9.0 \mathrm{mg} \mathrm{m}^{-2}$ day $^{-1}$, slightly higher than the values at ZMD, which fluctuate between 0.14 to $22.3 \mathrm{mg} \mathrm{m}^{-2}$ day $^{-1}$, with the mean value of $6.6 \mathrm{mg} \mathrm{m}^{-2}$ day $^{-1}$. Based on the calculation method described in Section 2.4, we try to estimate the annual deposition flux in two catchments. The results show that the annual deposition fluxes are 4050 tons at TTH basin and 40,920 tons at ZMD basin. The possible errors generated from the fact that a limited sampling point is insufficient to represent the average of the whole watershed. Although the mean daily DOC fluxes at ZMD are less than those at TTH, the annual deposition flux is much higher than the latter, which is related to its larger drainage area and greater precipitation. There are not enough proofs to confirm that direct relevance exists between the precipitation amounts and DOC fluxes even though the natural source of precipitation is probably the important source of the DOC concentration [73] (Figure 4a,b). For example, the DOC deposition flux at Beijing is $2.7 \mathrm{~g} \mathrm{~m}^{-2}$ year $^{-1}$, larger than the values in the SRYR, mainly because of its large number of DOCs produced by critical air pollution [54]. 

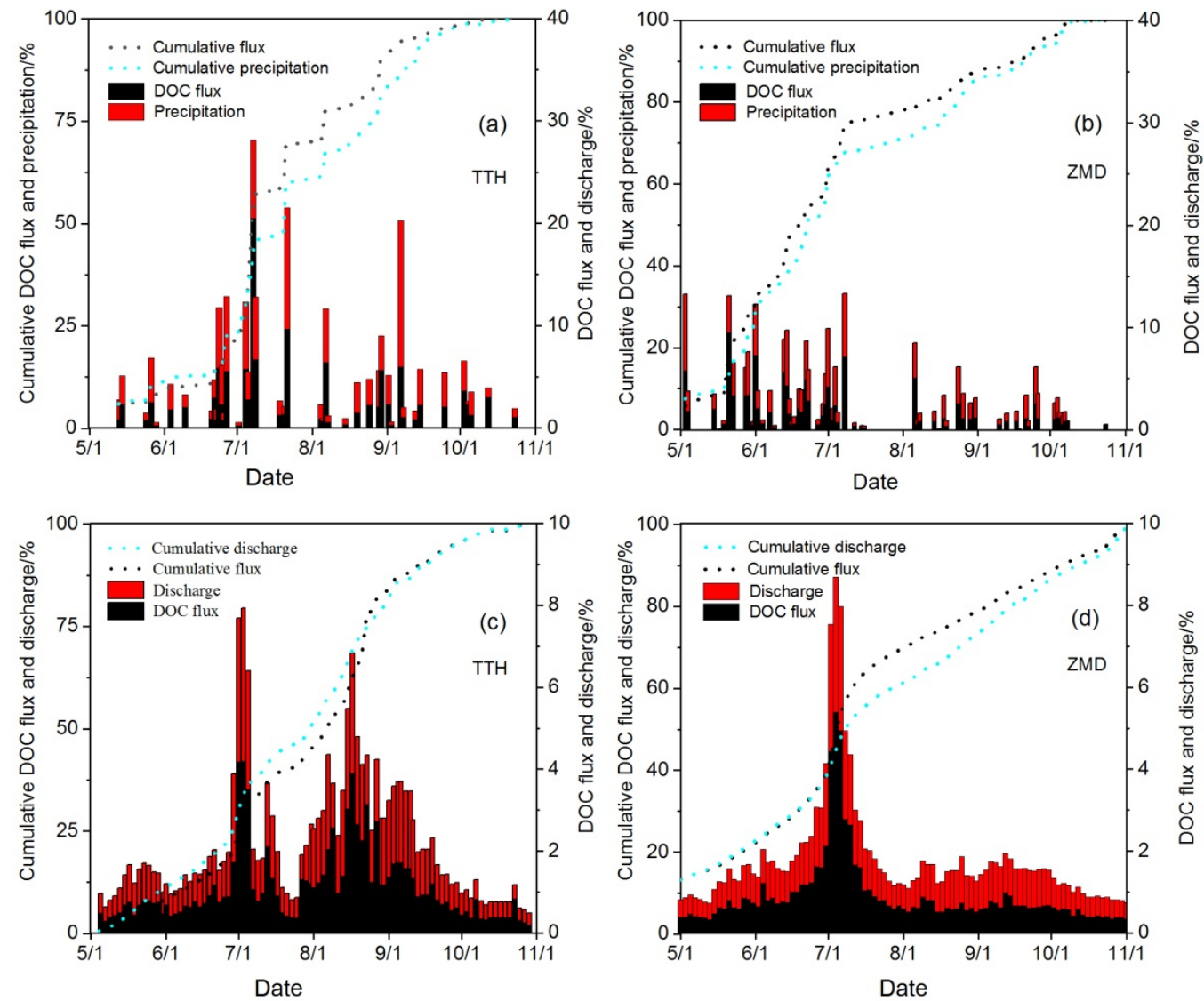

Figure 4. Temporal variations of DOC flux, discharge, and precipitation from May to October in the SRYR. (a) DOC deposition flux, precipitation, and their cumulative value at TTH; (b) DOC deposition flux, precipitation, and their cumulative value at ZMD; (c) riverine DOC flux, discharge, and their cumulative value at TTH; (d) riverine DOC flux, discharge, and their cumulative value at ZMD.

The concentration of the DOC in precipitation is comparable with that in river water; however, its flux is much greater than the latter. Even if we ignore the errors that may be caused by the calculation method, the ten times difference between the two still implies that the DOC deposition flux is much greater than the river transport flux, which may conflict with the existing research that global carbon exports from the terrestrial biosphere to rivers by leaching from plants and soil erosion [22]. In fact, direct transportation of DOC to rivers by precipitation is limited, most of which is carried to the land surface by rainfall and redistributed with the local water circulation. As shown in Figure 5, a portion of the DOCs are brought by surface runoff straight into the river together with those from the scouring and erosion of precipitation and surface flow; the other portion of them is filled into the soil layer through downward infiltration and soil water flow. For the latter, the DOC loaded by water blends fully with the soil layer, making biochemical reactions possible, and further alters the occurrence state of DOC [74]. Consequently, the heavy rains in late summer and autumn contribute to the washout of organic matter from fresh plants, which leads to an increase in the allochthonous DOC concentration in the river [75]. Additionally, the influx of terrigenous dissolved organic matter with groundwater during periods of low river runoff is one of the main sources of DOC concentration in river water [76]. In general, the water circulation and intricate hydraulic connection have a great impact on the occurrence status and quantity of DOC besides the complex biological effects and surface erosion in the catchment. 


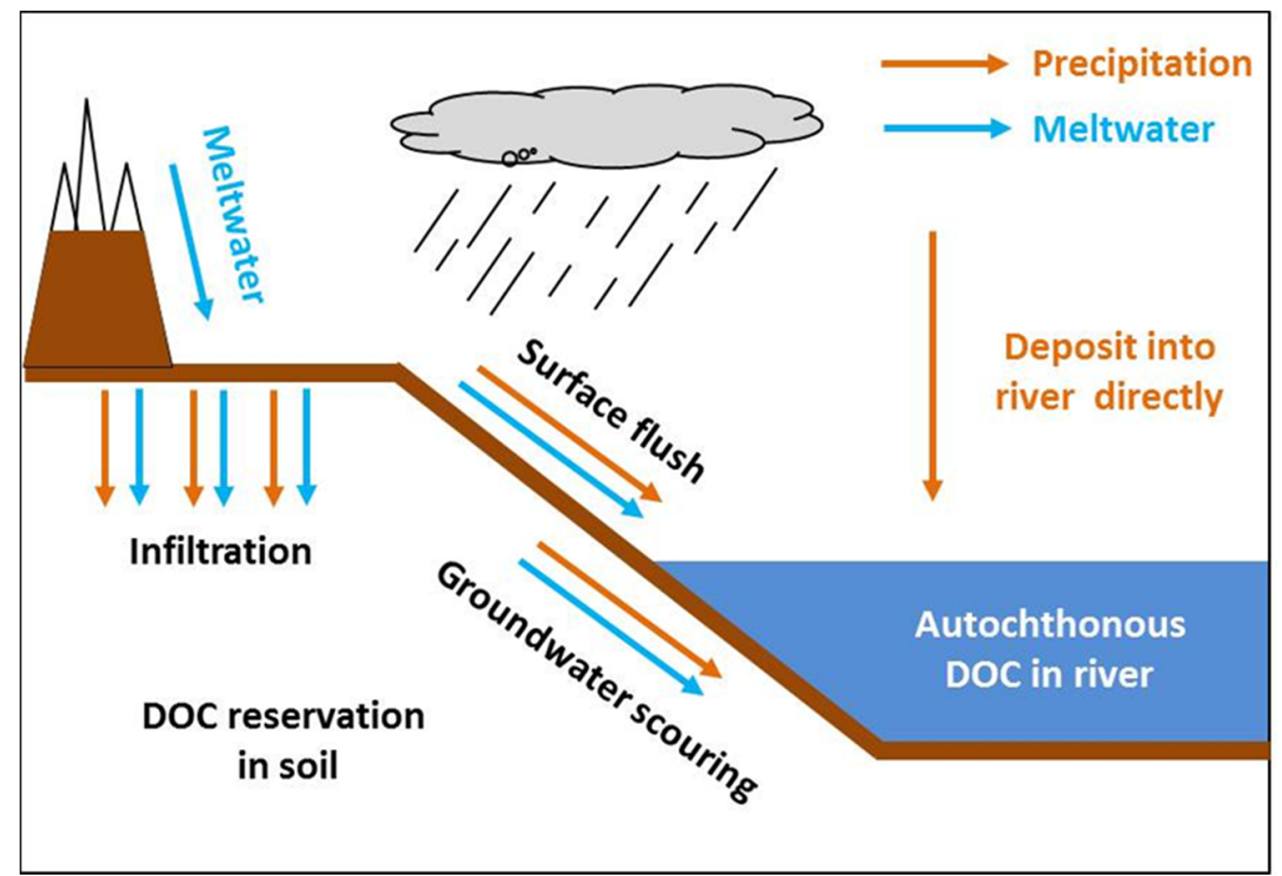

Figure 5. Schematic diagram of riverine DOC transportation in the SRYR. The blue arrows indicate the possible transportation of DOC under the influence of glacier/permafrost/frozen soil meltwater; the orange arrows indicate the moving process of DOC affected by precipitation.

Besides the allochthonous DOC, the amount of autochthonous DOC in rivers should not be underestimated, which may affect the DOC concentration in the river due to the internal production and carbon mineralization [26]. The research concludes that the internal production of DOC and mineralization to $\mathrm{CO}_{2}$ may contribute up to $28 \%$ of the total $\mathrm{CO}_{2}$ efflux in rivers [77]. That means the DOC concentration tested by us is actually the result of a combination of allochthonous and autochthonous processes. A part of them is emitted to the atmosphere in the form of carbon dioxide, part is buried in sediment, and the remaining part is carried to the downstream. In this analysis, we are unable to explore the internal production and consumption of carbon within aquatic systems based on the available data, but the effect of this process will reduce the mass of terrestrial carbon needed to support these flux estimates. However, further work is needed to partition the contribution of internal production and external transport within inland waters spatially to distinguish the source across terrestrial and aquatic ecosystems better.

\subsection{Spatial Distribution of DOC Concentration in Yangtze River}

The DOC concentrations at ZMD in the river water, precipitation, and groundwater are slightly lower than those at TTH (Table 1). At TTH, the daily air temperature was $4.1^{\circ} \mathrm{C}$ from May to October in 2015 , ranging between $-6.7^{\circ} \mathrm{C}$ and $11.6^{\circ} \mathrm{C}$. During the same period in 2014, $439 \mathrm{~mm}$ precipitation occurred in total. The mean discharge was $43.3 \mathrm{~m} \mathrm{~s}^{-1}$, with a variation range of 8.34 to $121 \mathrm{~m} \mathrm{~s}^{-1}$. At ZMD, the daily air temperature was $9.4^{\circ} \mathrm{C}$, fluctuated between $-0.4{ }^{\circ} \mathrm{C}$ and $17.1^{\circ} \mathrm{C}$. The precipitation and discharge were $364 \mathrm{~mm}$ and $529 \mathrm{~m} \mathrm{~s}^{-1}$ (varied from 240 to $2010 \mathrm{~m} \mathrm{~s}^{-1}$ ), respectively. Combined with regional hydrological and climatic characteristics, the reason for the higher DOC concentrations at TTH may be the more effective export of C-rich organic compounds from upstream permafrost and glacier ablation. 
Table 1. Mean concentration of DOC in river water, precipitation, and groundwater at different sampling sites in the Tibetan Plateau.

\begin{tabular}{|c|c|c|c|c|c|c|}
\hline Site & $\begin{array}{l}\text { Altitude } \\
\text { (m) }\end{array}$ & $\begin{array}{l}\text { Latitude } \\
\left({ }^{\circ} \mathrm{N}\right)\end{array}$ & $\begin{array}{l}\text { Longitude } \\
\left({ }^{\circ} \mathrm{E}\right)\end{array}$ & $\begin{array}{l}\text { Precipitation } \\
\quad\left(\mathrm{mg} \mathrm{L}^{-1}\right)\end{array}$ & $\begin{array}{c}\text { River } \\
\left(\mathrm{mg} \mathrm{L}^{-1}\right)\end{array}$ & $\begin{array}{l}\text { Groundwater } \\
\quad\left(\mathrm{mg} \mathrm{L}^{-1}\right)\end{array}$ \\
\hline $\mathrm{TTH}$ & 4533 & 34.23 & 92.45 & 1.34 & 1.24 & 2.44 \\
\hline ZMD & 3681 & 33.01 & 97.24 & 1.22 & 1.16 & 1.23 \\
\hline $\mathrm{YZ}-1$ * & 4717 & 33.43 & 92.04 & - & 1.02 & - \\
\hline YZ-2 * & 4547 & 34.39 & 92.75 & - & 1.32 & - \\
\hline YZ-3 * & 2958 & 31.41 & 98.54 & - & 0.67 & - \\
\hline YZ-4 * & 2368 & 29.39 & 99.54 & - & 1.87 & - \\
\hline
\end{tabular}

* Data from Qu et al., 2018 [57].

The DOC concentrations analyzed by Qu et al. at four sampling sites in the Tibetan Plateau are comparable with our study [57]. Figure 6 indicates the spatial distribution of DOC along the main stream of the SRYR. According to the latitude position of the sampling points and the DOC concentrations, the points are divided into four groups from north to south. As with the two northernmost points, closer to the source of the Yangtze River with the altitude more than $4500 \mathrm{~m}$, the DOC concentrations at ZMD and YZ-2 are relatively large, most probably affected by the ablation of glaciers and permafrost. TTH and $\mathrm{YZ}-1$, located between $33-33.5^{\circ} \mathrm{N}$, have rather comparable concentrations, which are lower than ZMD and YZ-2. The DOC concentration at YZ-3 presents the lowest value of $0.67 \mathrm{mg} \mathrm{L}^{-1}$ with the maximal flow rate, suggesting that dilution effects of the river water play a significant role. The decreasing trend in the DOC concentrations from north to south is terminated at YZ-4, in which the maximal concentration is observed $\left(1.87 \mathrm{mg} \mathrm{L}^{-1}\right)$. In contrast to the high population density and pollution input in the middle and lower part of Yangtze River, the SRYR is characterized by sparse population and unproductive vegetation. The DOC most likely acts to follow the natural quality; in other words, it is mainly influenced by natural factors: for instance, discharge, precipitation, air, and water temperature, etc. [78]. Compared with other sampling points, YZ-4 is situated at the southernmost point $\left(29.39^{\circ} \mathrm{N}\right)$ and the lowest altitude $(2368 \mathrm{~m})$, so relatively warmer air and water temperature and wider vegetation cover may enhance the DOC concentrations in the river [58,79].

Concluded by the previous research, the DOC concentrations are the lowest in the upper reach of the Yangtze River and increase in the middle and lower reaches, which is followed closely by the patterns of population density and pollution input along the river basin $[23,38,78]$. However, the DOC concentrations in our research are comparable with the value of the lower reaches reported in $2003\left(1.29 \mathrm{mg} \mathrm{L}^{-1}\right)$. This implies that, attributed to the profound changes that have occurred in the Tibetan Plateau, the DOC concentrations have evidently increased in the past years. With global warming, the climate-sensitive glaciers on the Tibetan Plateau have shrunk $\sim 10 \%$ between the years of 1970 and 2000 [38,80], which promotes evapotranspiration and positively affects local precipitation [81]. We can extrapolate that the rivers in the SRYR may release and transport more DOC in the future. 


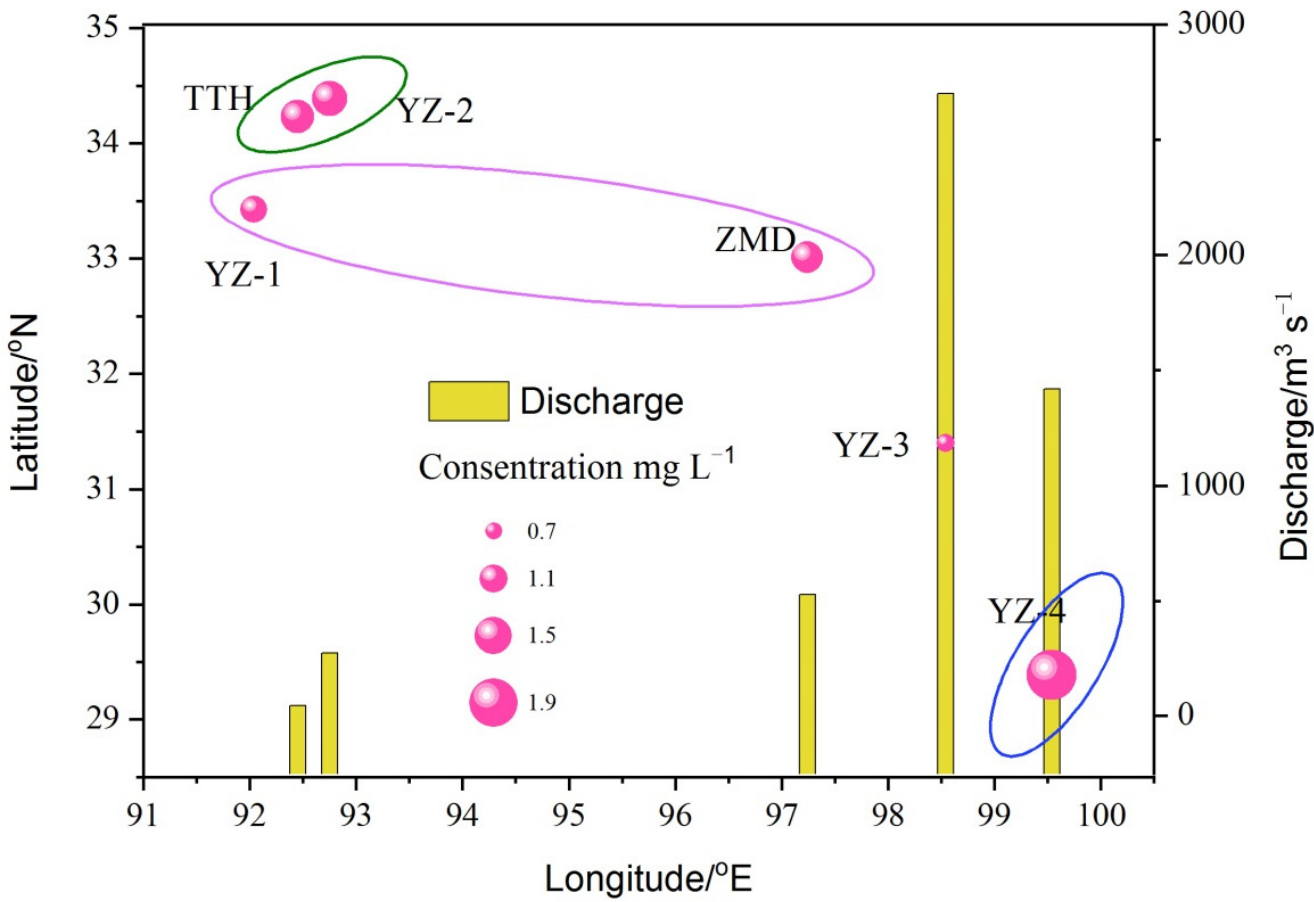

Figure 6. Spatial distribution of DOC concentration and the river discharge along the Yangtze River trunk stream. The histogram and solid circle represent the discharge and DOC concentration in sampling sites, respectively. Circle's diameter is proportional to the DOC concentration. The concentration and location data of YZ-1, YZ-2, YZ-3, and YZ-4 are from the reference [57].

\subsection{DOC Concentration and Inorganic Ion in River Water}

To better understand the DOC activities in the SRYR, we examine dissolved ions that originated from mineral weathering and organic matter cycling at ZMD (Figure 7). The nitrate concentrations $\left(\left[\mathrm{NO}_{3}{ }^{-}\right]\right)$in spring freshet $\left(440 \mu \mathrm{g} \mathrm{L}^{-1}\right)$ are lower than the whole year observations $\left(519 \mu \mathrm{g} \mathrm{L}^{-1}\right)$ and much lower than the winter values $\left(782 \mu \mathrm{g} \mathrm{L}^{-1}\right)$. The relationship between the DOC concentrations and $\left[\mathrm{NO}_{3}{ }^{-}\right]$are variable in different seasons (Figure 7a). In spring and autumn, the variation amplitudes of $\left[\mathrm{NO}_{3}{ }^{-}\right]$and DOC are small and indicate a reverse trend. In summer, although the $\left[\mathrm{NO}_{3}{ }^{-}\right]$fluctuated at a lower level, it had a positive trend with DOC. Identical with previous studies, the maximal $\left[\mathrm{NO}_{3}{ }^{-}\right]$appeared in the winter, a relatively cold season $[82,83]$, which could be comprehended as a complicated biochemical process. As previously mentioned, waters that access and go through soils near the permafrost table serve as a possible source of DOC in the summer; meanwhile, the increased input of $\mathrm{NO}_{3}{ }^{-}$to high latitude basins has been associated with warming conditions [84-86], which is why a weak positive correlation is captured in the summer. However, the fate of $\mathrm{NO}_{3}{ }^{-}$transfer from permafrost soils to streams depends on abiotic and biotic processes, complex interactions within the soil matrix, and residence times [85,87]. In winter, $\mathrm{NO}_{3}{ }^{-}$can accumulate as a result of continued microbial remineralization and reduced plant absorption due to the temperature decrease and biological activity weakening $[82,83]$. In addition, extractions from permafrost show that both $\mathrm{Ca}^{2+}$ and $\mathrm{NO}_{3}{ }^{-}$can be immobilized by freezing and enriched relative to other ions just below the active layer $[88,89]$. 

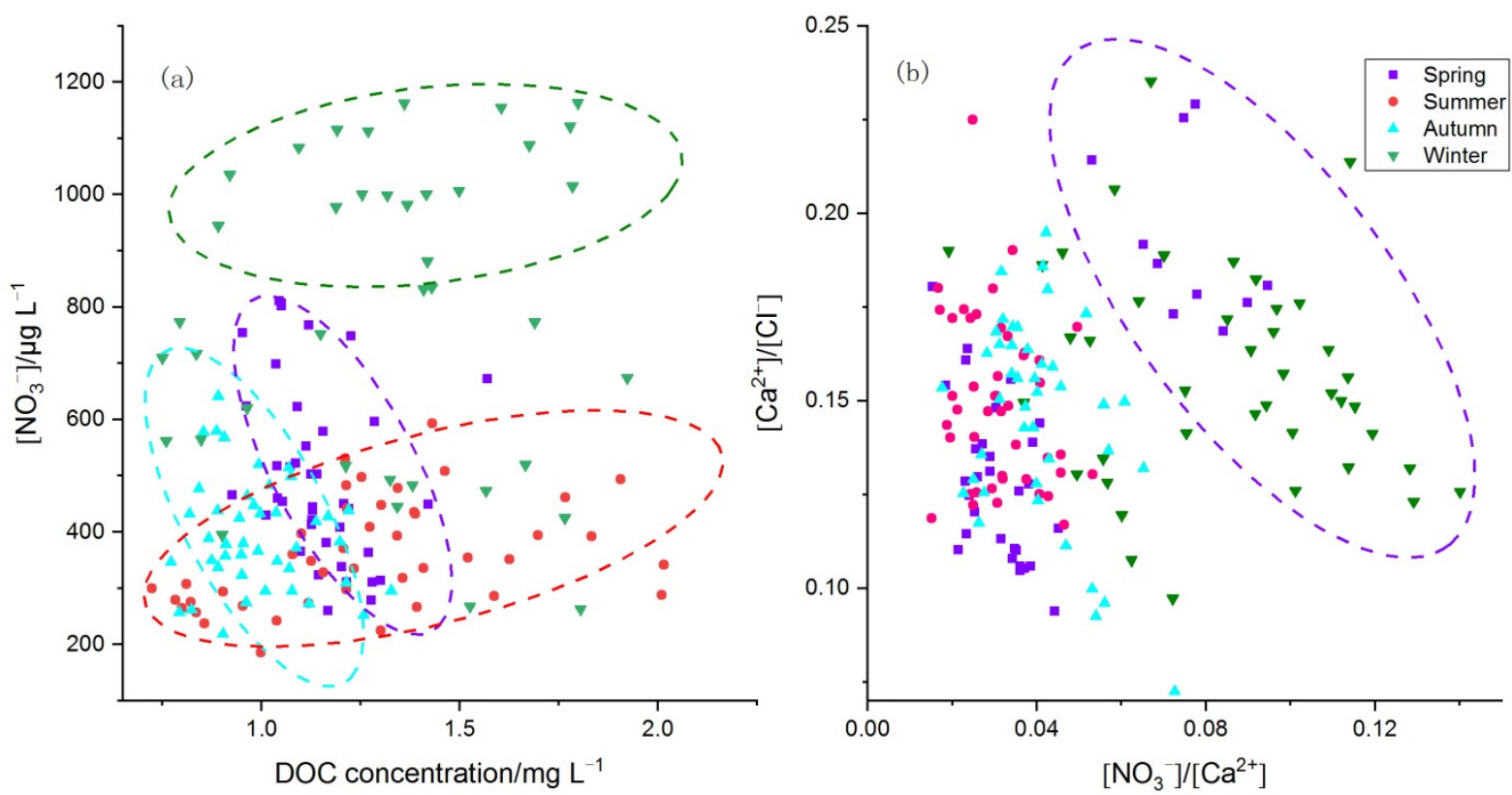

Figure 7. The relationships between $\mathrm{NO}_{3}{ }^{-}$and DOC concentrations (a) and the ratios for $\left[\mathrm{Ca}^{2+}\right] /\left[\mathrm{Cl}^{-}\right]$and $\left[\mathrm{NO}_{3}{ }^{-}\right] /\left[\mathrm{Ca}^{2+}\right](\mathbf{b})$ at Zhimenda (ZMD) gauging station in 2015.

Rivers do not exhibit higher abundances of $\mathrm{Ca}^{2+}$ relative to $\mathrm{Cl}^{-}$in different seasons (Figure $7 \mathrm{~b}$ ), suggesting that the variation in $\mathrm{Ca}^{2+}$ concentration $\left(\left[\mathrm{Ca}^{2+}\right]\right)$ is not remarkable during the observation period. Higher abundances of $\mathrm{NO}_{3}{ }^{-}$relative to $\mathrm{Ca}^{2+}$ in winter are presented, which may be related to the observable enrichment of $\mathrm{NO}_{3}{ }^{-}$. As a representative product of mineral weathering, $\mathrm{Ca}^{2+}$ is primarily derived from calcite and dolomite weathering. $\left[\mathrm{NO}_{3}{ }^{-}\right]$could be reflected by the organic matter cycling owing to its close association with the nutrient elements in near surface soils. Although the $\left[\mathrm{NO}_{3}{ }^{-}\right]$is much lower than $\left[\mathrm{Ca}^{2+}\right]$, the changes in $\left[\mathrm{NO}_{3}{ }^{-}\right]$dominate the ratios of both, implying that organic matter cycling guided by biological action is more significant to affect the soluble components in rivers compared with mineral weathering.

\section{Conclusions}

This paper presents the temporal and spatial variations of DOC concentrations and their hydrometeorological influence factors in the source region of the Yangtze River (SRYR) based on the continuous data from Tuotuohe (TTH) and Zhimenda (ZMD) gauging stations. The seasonal variations of both DOC concentrations and fluxes in different three end-members (river, precipitation, and groundwater) are considered in detail combined with the data of runoff, precipitation, and air temperature. The highest concentrations of riverine DOC appear in spring floods, which are closely related to the glacier ablation and permafrost thaws. With the continuous increase in melting and precipitation, bulk DOC is moved to the river around August by soil erosion. DOC concentrations in precipitation indicate certain variability related to the change in amount and frequency of precipitation. Although the DOC concentration in the groundwater is relatively stable, its hydraulic connection with precipitation and surface water make it fluctuate slightly. An estimated 459 and 6751 tons of DOC are transported by the river, respectively, at TTH and ZMD, which are far less than the deposition flux from precipitation. The deep exploration of the DOC redistribution with the water flow indicates that the direct transportation of DOC to rivers by precipitation is limited: most are carried to the land surface by rainfall and redistributed with local hydrological processes. The spatial variation in the DOC concentration along the main stream in the SRYR completely shows the attributes closely related to glacier and permafrost retreat, climate, and hydrological characteristics. Further exploration regarding 
the detailed aspects on controlling factors of DOC fluxes quantitatively would provide more information for the regional carbon cycle.

Author Contributions: Conceptualization, X.Y. and X.L.; methodology, X.Y.; software, R.W.; validation, C.W., Q.X. and X.L.; formal analysis, M.S.; investigation, X.Y. and X.L.; resources, X.Y. and X.L.; data curation, X.Y.; writing—original draft preparation, X.Y.; writing—review and editing, X.Y., X.L., M.S. and Q.X.; visualization, X.Y., X.L. and R.W.; supervision, X.L.; project administration, X.Y.; funding acquisition, X.Y. All authors have read and agreed to the published version of the manuscript.

Funding: This work was funded by the National Natural Science Foundation of China (grant numbers, 41761017, 42171053, 41671053), the Natural Science Foundation of Gansu Province (grant number, 18JR3RE247).

\section{Institutional Review Board Statement: Not applicable.}

Informed Consent Statement: Not applicable.

Data Availability Statement: Some or all data that support the findings of this study are available from the corresponding author upon reasonable request.

Acknowledgments: We thank Lixia Wang and Peng Zheng for sample analysis; Hongliang Li for field assistance and sample collection. Tseyang Sillanpää is also thanked for the language revision.

Conflicts of Interest: The authors declare no conflict of interest.

\section{References}

1. Pithan, F; Mauritsen, T. Arctic amplification dominated by temperature feedbacks in contemporary climate models. Nat. Geosci. 2014, 7, 181-184. [CrossRef]

2. Schuur, E.A.; McGuire, A.D.; Schädel, C.; Grosse, G.; Harden, J.W.; Hayes, D.J.; Hugelius, G.; Koven, C.D.; Kuhry, P.; Lawrence, D.M. Climate change and the permafrost carbon feedback. Nature 2015, 520, 171-179. [CrossRef] [PubMed]

3. Tarnocai, C.; Canadell, J.; Schuur, E.A.; Kuhry, P.; Mazhitova, G.; Zimov, S. Soil organic carbon pools in the northern circumpolar permafrost region. Glob. Biogeochem. Cycles 2009, 23. [CrossRef]

4. Zimov, S.A.; Schuur, E.A.; Chapin III, F.S. Permafrost and the global carbon budget. Science 2006, 312, 1612-1613. [CrossRef]

5. Guo, L.; Macdonald, R.W. Source and transport of terrigenous organic matter in the upper Yukon River: Evidence from isotope $(\delta 13 \mathrm{C}, \Delta 14 \mathrm{C}$, and $\delta 15 \mathrm{~N})$ composition of dissolved, colloidal, and particulate phases. Glob. Biogeochem. Cycles 2006, 20. [CrossRef]

6. Serreze, M.; Walsh, J.; Chapin, F.; Osterkamp, T.; Dyurgerov, M.; Romanovsky, V.; Oechel, W.; Morison, J.; Zhang, T.; Barry, R Observational evidence of recent change in the northern high-latitude environment. Clim. Chang. 2000, 46, 159-207. [CrossRef]

7. Douglas, T.A.; Blum, J.D.; Guo, L.; Keller, K.; Gleason, J.D. Hydrogeochemistry of seasonal flow regimes in the Chena River, a subarctic watershed draining discontinuous permafrost in interior Alaska (USA). Chem. Geol. 2013, 335, 48-62. [CrossRef]

8. Schuur, E.A.; Bockheim, J.; Canadell, J.G.; Euskirchen, E.; Field, C.B.; Goryachkin, S.V.; Hagemann, S.; Kuhry, P.; Lafleur, P.M.; Lee, H. Vulnerability of permafrost carbon to climate change: Implications for the global carbon cycle. Bioscience 2008, 58, 701-714. [CrossRef]

9. Frey, K.E.; Mcclelland, J.W. Impacts of permafrost degradation on arctic river biogeochemistry. Hydrol. Process. 2010, 23, 169-182. [CrossRef]

10. Hood, E.; Battin, T.J.; Fellman, J.; O'neel, S.; Spencer, R.G. Storage and release of organic carbon from glaciers and ice sheets. Nat. Geosci. 2015, 8, 91-96. [CrossRef]

11. Evans, C.; Monteith, D.; Cooper, D. Long-term increases in surface water dissolved organic carbon: Observations, possible causes and environmental impacts. Environ. Pollut. 2005, 137, 55-71. [CrossRef] [PubMed]

12. Dornblaser, M.M.; Striegl, R.G. Switching predominance of organic versus inorganic carbon exports from an intermediate-size subarctic watershed. Geophys. Res. Lett. 2015, 42, 386-394. [CrossRef]

13. Wei, X.; Hayes, D.J.; Fernandez, I.; Fraver, S.; Zhao, J.; Weiskittel, A. Climate and atmospheric deposition drive the inter-annual variability and long-term trend of dissolved organic carbon flux in the conterminous United States. Sci. Total Environ. 2021, 771, 145448. [CrossRef]

14. Cole, J.J.; Prairie, Y.T.; Caraco, N.F.; McDowell, W.H.; Tranvik, L.J.; Striegl, R.G.; Duarte, C.M.; Kortelainen, P.; Downing, J.A.; Middelburg, J.J.; et al. Plumbing the Global Carbon Cycle: Integrating Inland Waters into the Terrestrial Carbon Budget. Ecosystems 2007, 10, 172-185. [CrossRef]

15. Ferrera, C.M.; Jacinto, G.S.; Chen, C.T.A.; Lui, H.K. Organic Carbon Concentrations in High-and Low-Productivity Areas of the Sulu Sea. Sustainability 2018, 10, 1867. [CrossRef]

16. Musilova, M.; Tranter, M.; Wadham, J.; Telling, J.; Tedstone, A.; Anesio, A.M. Microbially driven export of labile organic carbon from the Greenland ice sheet. Nat. Geosci. 2017, 10, 360-365. [CrossRef]

17. Li, M.; Peng, C.; Zhou, X.; Yang, Y.; Guo, Y.; Shi, G.; Zhu, Q. Modeling global riverine DOC flux dynamics from 1951 to 2015. J. Adv. Model. Earth Syst. 2019, 11, 514-530. [CrossRef] 
18. Smith, H.J.; Foster, R.A.; McKnight, D.M.; Lisle, J.T.; Littmann, S.; Kuypers, M.M.M.; Foreman, C.M. Microbial formation of labile organic carbon in Antarctic glacial environments. Nat. Geosci. 2017, 10, 356-359. [CrossRef]

19. Yan, F.; Kang, S.; Li, C.; Zhang, Y.; Qin, X.; Li, Y.; Zhang, X.; Hu, Z.; Chen, P.; Li, X. Concentration, sources and light absorption characteristics of dissolved organic carbon on a medium-sized valley glacier, northern Tibetan Plateau. Cryosphere 2016, 10, 2611-2621. [CrossRef]

20. Li, Y.L.; He, W.; Wu, R.L.; Xing, B.; Xu, F.L. A general-applicable model for estimating the binding coefficient of organic pollutants with dissolved organic matter. Sci. Total Environ. 2019, 670, 226-235. [CrossRef]

21. Zheng, H.; Yan, Z.; Chen, J.; Jin, H.; Chen, C.T.A.; Liu, M.; Yan, Z.; Ji, Z. Seasonal variations of dissolved organic matter in the East China Sea using EEM-PARAFAC and implications for carbon and nutrient cycling. Sustainability 2018, 10, 1444. [CrossRef]

22. Galy, V.; Peucker-Ehrenbrink, B.; Eglinton, T. Global carbon export from the terrestrial biosphere controlled by erosion. Nature 2015, 521, 204-207. [CrossRef] [PubMed]

23. Wu, Y.; Zhang, J.; Liu, S.; Zhang, Z.; Yao, Q.; Hong, G.; Cooper, L. Sources and distribution of carbon within the Yangtze River system. Estuar. Coast. Shelf Sci. 2007, 71, 13-25. [CrossRef]

24. Spencer, R.G.; Hernes, P.J.; Aufdenkampe, A.K.; Baker, A.; Gulliver, P.; Stubbins, A.; Aiken, G.R.; Dyda, R.Y.; Butler, K.D.; Mwamba, V.L. An initial investigation into the organic matter biogeochemistry of the Congo River. Geochim. Cosmochim. Acta 2012, 84, 614-627. [CrossRef]

25. Monteith, D.T.; Stoddard, J.L.; Evans, C.D.; De Wit, H.A.; Forsius, M.; Hogasen, T.; Wilander, A.; Skjelkvale, B.L.; Jeffries, D.S.; Vuorenmaa, J.; et al. Dissolved organic carbon trends resulting from changes in atmospheric deposition chemistry. Nature 2007, 450, 537-540. [CrossRef]

26. Butman, D.; Stackpoole, S.; Stets, E.; McDonald, C.P.; Clow, D.W.; Striegl, R.G. Aquatic carbon cycling in the conterminous United States and implications for terrestrial carbon accounting. Proc. Natl. Acad. Sci. USA 2016, 113, 58-63. [CrossRef] [PubMed]

27. Clark, J.; Bottrell, S.; Evans, C.; Monteith, D.; Bartlett, R.; Rose, R.; Newton, R.; Chapman, P. The importance of the relationship between scale and process in understanding long-term DOC dynamics. Sci. Total Environ. 2010, 408, 2768-2775. [CrossRef] [PubMed]

28. Findlay, S.E. Increased carbon transport in the Hudson River: Unexpected consequence of nitrogen deposition? Front. Ecol. Environ. 2005, 3, 133-137. [CrossRef]

29. Li, T.; Bai, Y.; He, X.; Chen, X.; Chen, C.T.A.; Tao, B.; Pan, D.; Zhang, X. The relationship between poc export efficiency and primary production: Opposite on the shelf and basin of the northern South China Sea. Sustainability 2018, 10, 3634. [CrossRef]

30. Zhang, S.; Bai, Y.; Wen, X.; Ding, A.; Zhi, J. Seasonal and downstream alterations of dissolved organic matter and dissolved inorganic ions in a human-impacted mountainous tributary of the Yellow River, China. Environ. Sci. Pollut. Res. 2018, 25, 17967-17979. [CrossRef]

31. Zhao, D.; Dong, J.; Ji, S.; Huang, M.; Quan, Q.; Liu, J. Effects of contemporary land use types and conversions from wetland to paddy field or dry land on soil organic carbon fractions. Sustainability 2020, 12, 2094. [CrossRef]

32. Evans, C.D.; Chapman, P.J.; Clark, J.M.; Monteith, D.T.; Cresser, M.S. Alternative explanations for rising dissolved organic carbon export from organic soils. Glob. Chang. Biol. 2006, 12, 2044-2053. [CrossRef]

33. Wei, X.; Hayes, D.J.; Fernandez, I.; Zhao, J.; Fraver, S.; Chan, C.; Diao, J. Identifying key environmental factors explaining temporal patterns of DOC export from watersheds in the conterminous United States. J. Geophys. Res. Biogeosci. 2021, 126, e2020JG005813. [CrossRef]

34. Burd, K.; Tank, S.E.; Dion, N.; Quinton, W.L.; Spence, C.; Tanentzap, A.J.; Olefeldt, D. Seasonal shifts in export of DOC and nutrients from burned and unburned peatland-rich catchments, Northwest Territories, Canada. Hydrol. Earth Syst. Sci. 2018, 22, 4455-4472. [CrossRef]

35. Liu, S.; Zhang, Y.; Zhang, Y.; Ding, Y. Estimation of glacier runoff and future trends in the Yangtze River source region, China. J. Glaciol. 2009, 55, 353-362.

36. Li, X.Y.; Ding, Y.J.; Han, T.D.; Xu, J.Z.; Kang, S.C.; Wu, Q.B.; Sillanpää, M.; Yu, Z.B.; Yu, C.R. Seasonal variations of organic carbon and nitrogen in the upper basins of Yangtze and Yellow Rivers. J. Mt. Sci. 2017, 14, 1577-1590. [CrossRef]

37. Qu, B.; Sillanpää, M.; Li, C.; Kang, S.; Stubbins, A.; Yan, F.; Aho, K.S.; Zhou, F.; Raymond, P.A. Aged dissolved organic carbon exported from rivers of the Tibetan Plateau. PLoS ONE 2017, 12, e0178166.

38. Zhang, L.; Xue, M.; Wang, M.; Cai, W.J.; Wang, L.; Yu, Z. The spatiotemporal distribution of dissolved inorganic and organic carbon in the main stem of the Changiiang (Yangtze) River and the effect of the Three Gorges Reservoir. J. Geophys. Res. Biogeosci. 2014, 119, 741-757. [CrossRef]

39. Wang, X.; Ma, H.; Li, R.; Song, Z.; Wu, J. Seasonal fluxes and source variation of organic carbon transported by two major Chinese Rivers: The Yellow River and Changjiang (Yangtze) River. Glob. Biogeochem. Cycles 2012, 26. [CrossRef]

40. Yu, H.; Wu, Y.; Zhang, J.; Deng, B. Impact of extreme drought and the Three Gorges Dam on transport of particulate terrestrial organic carbon in the Changjiang (Yangtze) River. J. Geophys. Res. Earth Surf. 2011, 116. [CrossRef]

41. Yao, Z.; Liu, Z.; Huang, H.; Liu, G.; Wu, S. Statistical estimation of the impacts of glaciers and climate change on river runoff in the headwaters of the Yangtze River. Quat. Int. 2014, 336, 89-97. [CrossRef]

42. Gao, H.; He, X.; Ye, B.; Pu, J. Modeling the runoff and glacier mass balance in a small watershed on the Central Tibetan Plateau, China, from 1955 to 2008. Hydrol. Processes 2012, 26, 1593-1603. [CrossRef] 
43. Yu, G.A.; Brierley, G.; Huang, H.Q.; Wang, Z.; Blue, B.; Ma, Y. An environmental gradient of vegetative controls upon channel planform in the source region of the Yangtze and Yellow Rivers. Catena 2014, 119, 143-153. [CrossRef]

44. Yu, G.A.; Liu, L.; Li, Z.; Li, Y.; Huang, H.; Brierley, G.; Blue, B.; Wang, Z.; Pan, B. Fluvial diversity in relation to valley setting in the source region of the Yangtze and Yellow Rivers. J. Geogr. Sci. 2013, 23, 817-832. [CrossRef]

45. Li, X.; Ding, Y.; Xu, J.; He, X.; Han, T.; Kang, S.; Wu, Q.; Mika, S.; Yu, Z.; Li, Q. Importance of mountain glaciers as a source of dissolved organic carbon. J. Geophys. Res. Earth Surf. 2018, 123, 2123-2134. [CrossRef]

46. Li, X.; Ding, Y.; Han, T.; Kang, S.; Yu, Z.; Jing, Z. Seasonal controls of meltwater runoff chemistry and chemical weathering at Urumqi Glacier No. 1 in central Asia. Hydrol. Process. 2019, 33, 3258-3281. [CrossRef]

47. Bhatia, M.P.; Das, S.B.; Xu, L.; Charette, M.A.; Wadham, J.L.; Kujawinski, E.B. Organic carbon export from the Greenland ice sheet. Geochim. Cosmochim. Acta 2013, 109, 329-344. [CrossRef]

48. Schwab, M.S.; Hilton, R.G.; Raymond, P.A.; Haghipour, N.; Amos, E.; Tank, S.E.; Holmes, R.M.; Tipper, E.T.; Eglinton, T.I. An Abrupt Aging of Dissolved Organic Carbon in Large Arctic Rivers. Geophys. Res. Lett. 2020, 47, e2020GL088823. [CrossRef]

49. Gaillardet, J.; Dupré, B.; Louvat, P.; Allegre, C. Global silicate weathering and $\mathrm{CO}_{2}$ consumption rates deduced from the chemistry of large rivers. Chem. Geol. 1999, 159, 3-30. [CrossRef]

50. Tank, S.E.; Raymond, P.A.; Striegl, R.G.; McClelland, J.W.; Holmes, R.M.; Fiske, G.J.; Peterson, B.J. A land-to-ocean perspective on the magnitude, source and implication of DIC flux from major Arctic rivers to the Arctic Ocean. Glob. Biogeochem. Cycles 2012, 26. [CrossRef]

51. Jiang, L.; Yao, Z.; Liu, Z.; Wang, R.; Wu, S. Hydrochemistry and its controlling factors of rivers in the source region of the Yangtze River on the Tibetan Plateau. J. Geochem. Explor. 2015, 155, 76-83. [CrossRef]

52. Li, X.; Ding, Y.; Han, T.; Sillanpää, M.; Jing, Z.; You, X.; Liu, S.; Yang, C.; Yu, C.; Li, G. Seasonal and interannual changes of river chemistry in the source region of Yellow River, Tibetan Plateau. Appl. Geochem. 2020, 119. [CrossRef]

53. Li, C.; Yan, F.; Kang, S.; Chen, P.; Qu, B.; Hu, Z.; Sillanpää, M. Concentration, sources, and flux of dissolved organic carbon of precipitation at Lhasa city, the Tibetan Plateau. Environ. Sci. Pollut. Res. 2016, 23, 12915-12921. [CrossRef]

54. Pan, Y.; Wang, Y.; Xin, J.; Tang, G.; Song, T.; Wang, Y.; Li, X.; Wu, F. Study on dissolved organic carbon in precipitation in Northern China. Atmos. Environ. 2010, 44, 2350-2357. [CrossRef]

55. Dittmar, T.; Kattner, G. The biogeochemistry of the river and shelf ecosystem of the Arctic Ocean: A review. Mar. Chem. 2003, 83, 103-120. [CrossRef]

56. Dai, M.; Yin, Z.; Meng, F.; Liu, Q.; Cai, W.J. Spatial distribution of riverine DOC inputs to the ocean: An updated global synthesis Curr. Opin. Environ. Sustain. 2012, 4, 170-178. [CrossRef]

57. Qu, B.; Sillanpaa, M.; Kang, S.; Yan, F.; Li, Z.; Zhang, H.; Li, C. Export of dissolved carbonaceous and nitrogenous substances in rivers of the "Water Tower of Asia". J. Environ. Sci. 2018, 65, 53-61. [CrossRef]

58. Meybeck, M. Carbon, nitrogen, and phosphorus transport by world rivers. Am. J. Sci. 1982, 282, 401-450. [CrossRef]

59. Jobbágy, E.G.; Jackson, R.B. The vertical distribution of soil organic carbon and its relation to climate and vegetation. Ecol. Appl. 2000, 10, 423-436. [CrossRef]

60. Wang, G.; Li, Y.; Wang, Y.; Wu, Q. Effects of permafrost thawing on vegetation and soil carbon pool losses on the Qinghai-Tibet Plateau, China. Geoderma 2008, 143, 143-152.

61. Mann, P.; Davydova, A.; Zimov, N.; Spencer, R.G.; Davydov, S.; Bulygina, E.; Zimov, S.; Holmes, R. Controls on the composition and lability of dissolved organic matter in Siberia's Kolyma River basin. J. Geophys. Res. Biogeosci. 2012, 117. [CrossRef]

62. Petrone, K.C.; Jones, J.B.; Hinzman, L.D.; Boone, R.D. Seasonal export of carbon, nitrogen, and major solutes from Alaskan catchments with discontinuous permafrost. J. Geophys. Res. Biogeosci. 2006, 111. [CrossRef]

63. Kane, D.; Hinzman, L.; Benson, C.; Everett, K. Hydrology of Imnavait Creek, an arctic watershed. Ecography 1989, 12, 262-269. [CrossRef]

64. Liljedahl, A.K.; Boike, J.; Daanen, R.P.; Fedorov, A.N.; Frost, G.V.; Grosse, G.; Hinzman, L.D.; Iijma, Y.; Jorgenson, J.C.; Matveyeva, N. Pan-Arctic ice-wedge degradation in warming permafrost and its influence on tundra hydrology. Nat. Geosci. 2016, 9, 312-318. [CrossRef]

65. McCartney, S.E.; Carey, S.K.; Pomeroy, J.W. Intra-basin variability of snowmelt water balance calculations in a subarctic catchment. Hydrol. Process. Int. J. 2006, 20, 1001-1016. [CrossRef]

66. Teufel, B.; Sushama, L. Abrupt changes across the Arctic permafrost region endanger northern development. Nat. Clim. Chang. 2019, 9, 858-862. [CrossRef]

67. Li, Z.; Li, Z.; Feng, Q.; Zhang, B.; Gui, J.; Xue, J.; Gao, W. Runoff dominated by supra-permafrost water in the source region of the Yangtze river using environmental isotopes. J. Hydrol. 2020, 582, 124506. [CrossRef]

68. Connon, R.; Devoie, É.; Hayashi, M.; Veness, T.; Quinton, W. The influence of shallow taliks on permafrost thaw and active layer dynamics in subarctic Canada. J. Geophys. Res. Earth Surf. 2018, 123, 281-297. [CrossRef]

69. Walvoord, M.A.; Voss, C.I.; Ebel, B.A.; Minsley, B.J. Development of perennial thaw zones in boreal hillslopes enhances potential mobilization of permafrost carbon. Environ. Res. Lett. 2019, 14, 015003. [CrossRef]

70. Plaza, C.; Pegoraro, E.; Bracho, R.; Celis, G.; Crummer, K.G.; Hutchings, J.A.; Pries, C.E.H.; Mauritz, M.; Natali, S.M.; Salmon, V.G. Direct observation of permafrost degradation and rapid soil carbon loss in tundra. Nat. Geosci. 2019, 12, 627-631. [CrossRef]

71. Wang, G.; Mao, T.; Chang, J.; Song, C.; Huang, K. Processes of runoff generation operating during the spring and autumn seasons in a permafrost catchment on semi-arid plateaus. J. Hydrol. 2017, 550, 307-317. 
72. Huang, J.; Kang, S.; Shen, C.; Cong, Z.; Liu, K.; Wang, W.; Liu, L. Seasonal variations and sources of ambient fossil and biogenic-derived carbonaceous aerosols based on 14C measurements in Lhasa, Tibet. Atmos. Res. 2010, 96, 553-559. [CrossRef]

73. Yan, G.; Kim, G. Dissolved organic carbon in the precipitation of Seoul, Korea: Implications for global wet depositional flux of fossil-fuel derived organic carbon. Atmos. Environ. 2012, 59, 117-124. [CrossRef]

74. You, X.; Li, X. Seasonal Variations in Dissolved Organic Carbon in the Source Region of the Yellow River on the Tibetan Plateau. Water 2021, 13, 2901. [CrossRef]

75. Gordeev, V.V.; Kochenkova, A.I.; Lokhov, A.S.; Yakovlev, A.E.; Belorukov, S.K.; Fedulov, V.Y. Seasonal and Inter Annual Variations between Concentrations and Fluxes of Dissolved and Particulate Organic Carbon, Iron and Manganese from the Northern Dvina River to the White Sea. Oceanology 2021, 61, 34-47. [CrossRef]

76. Johnston, S.E.; Shorina, N.; Bulygina, E.; Vorobjeva, T.; Chupakova, A.; Klimov, S.I.; Kellerman, A.M.; Guillemette, F.; Shiklomanov, A.; Podgorski, D.C. Flux and Seasonality of Dissolved Organic Matter From the Northern Dvina (Severnaya Dvina) River, Russia. J. Geophys. Res. Biogeosci. 2018, 123, 1041-1056. [CrossRef]

77. Hotchkiss, E.R.; Hall, R.O.; Sponseller, R.A. Sources of and processes controlling $\mathrm{CO}_{2}$ emissions change with the size of streams and rivers. Nat. Geosci. 2015, 8, 696-712. [CrossRef]

78. Wen, Z.; Song, K.; Shang, Y.; Lyu, L.; Tao, H.; Liu, G. Natural and anthropogenic impacts on the DOC characteristics in the Yellow River continuum. Environ. Pollut. 2021, 287, 117231. [CrossRef]

79. Raymond, P.A.; Bauer, J.E. Bacterial consumption of DOC during transport through a temperate estuary. Aquat. Microb. Ecol. 2000, 22, 1-12. [CrossRef]

80. Kang, S.; Xu, Y.; You, Q.; Flügel, W.A.; Pepin, N.; Yao, T. Review of climate and cryospheric change in the Tibetan Plateau. Environ. Res. Lett. 2010, 5, 015101. [CrossRef]

81. Du, J.; Ma, Y. Climatic trend of rainfall over Tibetan Plateau from 1971 to 2000. Acta Geogr. Sin. 2004, 59, 375-382.

82. Edwards, K.A.; Jefferies, R.L. Inter-annual and seasonal dynamics of soil microbial biomass and nutrients in wet and dry low-Arctic sedge meadows. Soil Biol. Biochem. 2013, 57, 83-90. [CrossRef]

83. Treat, C.C.; Wollheim, W.M.; Varner, R.K.; Bowden, W.B. Longer thaw seasons increase nitrogen availability for leaching during fall in tundra soils. Environ. Res. Lett. 2016, 11, 064013. [CrossRef]

84. Fouché, J.; Christiansen, C.; Lafrenière, M.; Grogan, P.; Lamoureux, S. Canadian permafrost stores large pools of ammonium and optically distinct dissolved organic matter. Nat. Commun. 2020, 11, 1-11. [CrossRef]

85. Harms, T.K.; Jones, J.B. Thaw depth determines reaction and transport of inorganic nitrogen in valley bottom permafrost soils: Nitrogen cycling in permafrost soils. Glob. Chang. Biol. 2012, 18, 2958-2968. [CrossRef] [PubMed]

86. McClelland, J.; Stieglitz, M.; Pan, F.; Holmes, R.; Peterson, B. Recent changes in nitrate and dissolved organic carbon export from the upper Kuparuk River, North Slope, Alaska. J. Geophys. Res. Biogeosci. 2007, 112. [CrossRef]

87. Spencer, R.G.; Mann, P.J.; Dittmar, T.; Eglinton, T.I.; McIntyre, C.; Holmes, R.M.; Zimov, N.; Stubbins, A. Detecting the signature of permafrost thaw in Arctic rivers. Geophys. Res. Lett. 2015, 42, 2830-2835. [CrossRef]

88. Kokelj, S.; Burn, C.R. Geochemistry of the active layer and near-surface permafrost, Mackenzie delta region, Northwest Territories, Canada. Can. J. Earth Sci. 2005, 42, 37-48. [CrossRef]

89. Reyes, F.R.; Lougheed, V.L. Rapid nutrient release from permafrost thaw in arctic aquatic ecosystems. Arct. Antarct. Alp. Res. 2015, 47, 35-48. [CrossRef] 